\title{
PENGARUH MODEL PEMBELAJARAN KOOPERATIF TIPE THINK PAIR SQUARE (TPSq) DIKOMBINASIKAN DENGAN PENDEKATAN PROBLEM SOLVING TERHADAP HASIL BELAJAR BIOLOGI SISWA KELAS VIII SMPN 5 BATAM
}

\section{THE EFFECT OF THE COOPERATIVE LEARNING MODEL; THINK PAIR SQUARE TYPE (TPSq) AND PROBLEM SOLVING APPROACH COMBINATION TOWARD STUDENTS' BIOLOGY LEARNING OUTCOMES AT CLASS VIII SMPN 5 BATAM}

\author{
Masrudi ${ }^{1}$, Destaria Sudirman ${ }^{2 *}$, Ramses $^{3}$ \\ ${ }^{123}$ Program Studi Pendidikan Biologi, FKIP, Universitas Riau Kepulauan, Batam \\ *Korespondensi: destaria_sudirman@gmail.com
}

\begin{abstract}
Abstrak
Penelitian ini bertujuan untuk mengetahui pengaruh model pembelajaran kooperatif tipe Think Pair Square (TPSq) yang dikombinasikan dengan pendekatan Problem Solving (PS) terhadap hasil belajar biologi siswa kelas VIII SMPN 5 Batam. Jenis penelitian adalah Eksperimen Semu, siswa dibagi dua kelas, yaitu kelas eksperimen kelas (VIII ${ }^{\mathrm{A}}$ ) dengan model pembelajaran TPSq dengan PS sedangkan kelas kontrol (VIII ${ }^{\mathrm{B}}$ ) menggunakan metode Ceramah. Data penelitian berupa tes yang dilaksanakan setelah pemberian materi/konsep yang dibahas dipelajari dan tes berbentuk pilihan ganda (multiple choice test) yang diberikan pada kelas kontrol maupun kelas eksperimen. Berdasarkan hasil analisis data tes akhir didapat rata-rata hasil belajar biologi siswa pada kelas eksperimen 80,00 dan pada kelas kontrol 68,00. Berarti hasil belajar biologi siswa dengan model pembelajaran TPSq yang dikombinasikan dengan Problem Solving lebih tinggi dari pada dengan menggunakan metode ceramah, hal disebabkan karena model pembelajaran TPS $q$ ini menjadikan siswa termotivasi untuk belajar biologi.
\end{abstract}

Kata Kunci : Pengaruh, Model Pembelajaran, Hasil Belajar

\begin{abstract}
This study aims to determine effect of the cooperative learning model; Think Pair Square (TPSq) and approach of Problem Solving (PS) combination toward students Biology learning outcomes at class VIII SMPN 5 Batam. The type of research was a Quasi Experiment, students were divided into two classes, classroom experiments (VIII ${ }^{A}$ ) with learning model TPSq and PS comination, meanwhile the control class $\left(V_{I I I}{ }^{B}\right)$ using convetional methods. The research data was tests which conducted after the provision of material / concepts studied being discussed, and multiple choice test (multiple choice test) provided on the control class and experimental class. Based on the analysis of final test results obtained on average student studying biology at 80.00, either experimental class and the control class 68.00. it means, students biology learning outcome with learning model TPSq and PS combination were higher than conventional method, it was because this model makes students are motivated to learn biology.
\end{abstract}

Keywords: Effects, Learning Models, Learning Outcomes

\section{PENDAHULUAN}

Peranan guru dalam proses pembelajaran tidak hanya sebagai informator, tetapi juga sebagai organisator, motivator, pengarah (direktor), inisiator, transmitter, fasilitator, 
mediator dan evaluator (Sardiman, 2006). Sejalan dengan ini, Mulyasa (2008) menyatakan bahwa guru juga berperan sebagai perencana (designer), pelaksana (implementer) dan penilai (evaluator) pembelajaran. Keberhasilan proses dan hasil belajar di kelas dipengaruhi oleh beberapa faktor antara lain guru dan siswa. Selain menguasai materi, seorang guru juga dituntut untuk menguasai strategi-strategi dalam penyampaian materi pelajaran. Strategi yang digunakan guru akan berpengaruh terhadap respon siswa terhadap pembelajaran. Apabila guru berhasil menciptakan suasana yang menyebabkan siswa termotivasi aktif dalam belajar, akan memungkinkan terjadi peningkatan hasil belajar.

Berdasarkan hasil observasi penulis di SMP Negeri 5 Batam, metode pembelajaran yang dilakukan bersifat umum menggunakan metode ceramah. Siswa belum terlibat secara aktif dalam pembelajaran sehingga siswamerasa bosan dan tidak bersemangat dalam belajar dan pada akhirnya akan berdampak pada hasil belajar yang diperoleh. Menurut data yang penulis dapatkan saat observasi langsung pada guru mata pelajaran biologi terlihat bahwa rata-rata nilai ulangan harian Biologi kelas VIII belum memuaskan, karena masih dibawah Kriteria Ketuntasan Minimal (KKM) yang ditetapkan sekolah yakni 70 .

Untuk mengatasi hal ini diperlukan strategi pembelajaran yang mampu membuat siswa lebih berperan aktif. Salah satu model pembelajaran yang dapat digunakan adalah model pembelajaran kooperatif tipe Think Pair Square (berpikir-berpasangan-berempat). Model pembelajaran ini bisa mengatasi sifat pasif siswa dalam belajar, karena siswa dituntut untuk berpikir secara mandiri, berbagi dengan pasangannya dan bekerja dalam kelompok. Lie (2004) menyatakan bahwa "model ini bisa digunakan untuk meningkatkan motivasi siswa dalam belajar". Model pembelajaran Think Pair Square (TPSq) mempunyai keunggulan yakni siswa selalu berpartisipasi, karena selain siswa bekerja secara mandiri, siswa juga diberi lebih banyak kesempatan untuk berbagi dengan teman yang lainnya. Dari hasil penelitian Martasari (2008) yang menggunakan soal pada proseps pembelajarannya dan Melinda (2009) yang menggunakan kuis pada proses pembelajarannya, terungkap bahwa model pembelajaran $T P S q$ mampu meningkatkan hasil belajar siswa. Pendekatan Problem Solving akan memiliki nilai positif bagi siswa, diantaranya yaitu akan memancing siswa untuk berfikir kritis, cepat, dan logis. Melalui tugas ini siswa mampu memahami materi pelajaran lebih cepat, sehingga biologi yang selama ini dianggap sebagai disiplin ilmu yang bersifat hafalan akan berubah menjadi ilmu 
yang menarik dan butuh pemahaman bukan hafalan. Pada akhirnya pelajaran sains biologi akan menjadi sangat menarik bagi siswa dan berpengaruh positif terhadap peningkatan hasil belajar siswa.

Berdasarkan uraian di atas penulis akan melakukan penelitian tentang Pengaruh Model Pembelajaran Kooperatif Tipe Think Pair Square (TPSq) yang Dikombinasikan dengan Pendekatan Problem Solving terhadap hasil belajar biologi siswa.

\section{METODOLOGI}

Penelitian ini termasuk penelitian Eksperimen Semu. Dalam hal ini siswa dibagi ke dalam dua kelas, yaitu kelas eksperimen dan kelas kontrol. Pada kelas eksperimen digunakan pembelajaran kooperatif tipeTPSq yang dikombinasikan dengan pendekatan Problem Solving.

Model rancangan penelitian yang digunakan adalah Randomized Control Group Posttest Only Design yang digambarkan sebagai berikut:

Tabel 1. Rancangan penelitian

\begin{tabular}{ccc}
\hline Kelas & Treatment & Posttest \\
\hline Eksperimen & $\mathrm{X}$ & $\mathrm{T}$ \\
Kontrol & - & $\mathrm{T}$ \\
\hline
\end{tabular}

(Sumber: Yusuf, 2007)

Keterangan:

X : Pembelajaran kooperatif tipe TPSq yang dikombinasikandengan pendekatan Problem Solving.

- : Pembelajaranmetode ceramah

$\mathrm{T}$ : Tes akhiryang diberikan kepada kelas eksperimen dan kelas kontrol.

Populasi dalam penelitian ini adalah seluruh siswa kelas VIII SMP Negeri 5 Batam. Jumlah siswa dalam 2 kelas yaitu Kelas VIII.1 siswa 30 dengan nilai rerata 67 dan Kelas VIII.2 1 siswa 30 dengan nilai rerata 68.

Dalam pengambilan sampel, teknik sampling yang digunakan adalah Total Sampling (Arikunto, 2006). Untuk menentukan kelas eksperimen dan kelas kontrol dilihat dari nilai rata-rata, maka yang menjadi kelas sampel adalah kelas VIII.1 sebagai kelas eksperimen dan kelas VIII.2 sebagai kelas kontrol.

Variabel pada penelitian ini digunakan dua variabel, yaitu: a) Variabel bebas adalah perlakuan yang diberikan kepada kelas eksperimen yaitu pembelajaran kooperatif tipe TPS $q$ yang dikombinasikan dengan pendekatan Problem Solving; dan b) Variabel terikat 
adalah hasil belajar biologi siswa setelah diberikan tes sesudah perlakuan. Tahap evaluasi memberikan soal sebagai tes akhir pada kedua kelas yaitu kelas eksperimen dan kelas kontrol untuk menentukan hasil yang diperoleh melalui tes instrumen dengan materi/konsep yang dibahas telah selesai dipelajari. Tes berbentuk tertulis pilihan ganda (multiple choice test). Sebelum instrumen test dibuat dilakukan uji validitas atau validitas kurikuler, (Arikunto, 2012).Untuk kevalitan isi, disesuaikan dengan isi materi pelajaran dalam kurikulum. Dengan analisis menggunakan rumus Point biserial correlation $\left(r_{p b i s}\right)$. Uji Indeks Kesukaran butir soal dengan pendekatan Indeks kesukaran soal dengan klasifikasi kriteria berdasarkan Arikunto (2012). Pengujian lanjut adalah Reliabilitas adalah suatu ukuran apakah tes tersebut dapat dipercaya untuk digunakan sebagai alat ukur atau pengumpul data. Untuk menentukan reliabilitas tes dalam penelitian ini digunakan rumus Kuder-Richardson (K-R. 21).

Teknik analisis data untuk menguji hipotesis yang digunakan adalah uji beda dua rata-rata $\left(\mathrm{T}_{\text {test }}\right)$. Untuk uji beda dua rata-rata, terlebih dahulu dilakukan uji normalitas dan uji homogenitas. Uji Normalitas menggunakan rumus Lilliofors (Sudjana, 2005). Metode Lilliefors yakni menggunakan data dasar yang belum diolah dalam tabel distribusi frekuensi Kriteria Pengujian adalah sebagai berikut: a) Jika $\mathrm{L}_{\text {hitung }} \geq \mathrm{L}_{\text {tabel }}$ maka artinya distribusi data tidak normal; dan b) Jika $\mathrm{L}_{\text {hitung }} \leq \mathrm{L}_{\text {tabel }}$ maka artinya data distribusi normal. Uji selanjutnya Uji homogenitas varians dilakukan setelah tes akhir, yang bertujuan untuk melihat variansi data hasil belajar pada kedua kelas sampel apakah homogen atau tidak (Arikunto, 2012). Pengujian homogenitas menggunakan Uji F yaitu untuk menguji homogenitas sebaran dua kelompok data varians terbesar dibanding varians terkecil yang menggunakan tabel F. Terakhir adalah dilakukan uji hipotesis dengan menggunakan uji kesamaan dua rata-rata nilai. Dari analisis yang telah dilakukan diperoleh data terdistribusi normal dan kedua kelompok data mempunyai varians yang homogen. Uji t adalah salah satu statistik yang digunakan untuk menguji kebenaran atau kepalsuan hipotesis yang menyatakan bahwa diantara dua buah mean sample yang diambil secara random dari populasi yang sama, tidak terdapat perbedaan signifikan (Sudjana, 2005).

\section{HASIL DAN PEMBAHASAN}

Dari penelitian yang telah dilakukan pada kedua kelas sampel, diperoleh data tentang hasil belajar siswa. Data tersebut diperoleh dari tes akhir pada kegiatan penelitian. 
Pada tes akhir digunakan 20 soal objektif. Pada kelas eksperimen tes akhir diikuti oleh seluruh siswa yaitu 30 orang dan pada kelas kontrol diikuti oleh 30 orang. Sehingga didapat perolehan data nilai hasil belajar siswa yang dapat dilihat pada tabel 2 .

Tabel 2. Distribusi frekuensi data hasil penelitian kelas eksperimen $\left(\mathrm{X}_{1}\right)$ dan Kontrol $\left(\mathrm{X}_{2}\right)$

\begin{tabular}{ccccccc}
\hline No & $\begin{array}{c}\text { Skor } \\
\text { kelas } \\
\text { eksperimen }\end{array}$ & Frekuensi & Nilai & $\begin{array}{c}\text { Skor } \\
\text { kelas } \\
\text { kontrol }\end{array}$ & frekuensi & Nilai \\
\hline 1 & 12 & 1 & 60,00 & 9 & 1 & 45,00 \\
2 & 13 & 2 & 65,00 & 10 & 1 & 50,00 \\
3 & 14 & 4 & 70,00 & 11 & 2 & 55,00 \\
4 & 15 & 5 & 75,00 & 12 & 4 & 60,00 \\
5 & 16 & 7 & 80,00 & 13 & 6 & 65,00 \\
6 & 17 & 5 & 85,00 & 14 & 7 & 70,00 \\
7 & 18 & 3 & 90,00 & 15 & 4 & 75,00 \\
8 & 19 & 2 & 95,00 & 16 & 2 & 80,00 \\
9 & 20 & 1 & 100 & 17 & 2 & 90,00 \\
10 & & & & 18 & 1 & 68,00 \\
\hline Jumlah & & 30 & 80,00 & & 30 & \\
\hline
\end{tabular}

Berdasarkan hasil analisis jawaban siswa pada kegiatan tes akhir diperoleh data nilai rata-rata tes, simpangan baku, dan varians kelas eksperimen dan kelas kontrol yang seperti pada Tabel berikut:

Tabel 3. Rekapitulasi nilai rerata kelas eksperimen $\left(\mathrm{X}_{1}\right)$ dan Kontrol $\left(\mathrm{X}_{2}\right)$

\begin{tabular}{ccccc}
\hline Kelas & $\mathbf{N}$ & $\bar{X}$ & $\mathbf{S}$ & $\mathbf{S}^{2}$ \\
\hline Eksperimen & 30 & 80,00 & 9,55 & 91,26 \\
Kontrol & 30 & 68,00 & 10,30 & 106,01 \\
\hline
\end{tabular}

Berdasarkan Tabel tersebut dapat dilihat bahwa hasil belajar siswa pada kelas eksperimen yang diberi perlakuan dengan pemberian model kooperatif tipe $T P S q$ yang dikombinasikan dengan pendekatan Problem Solving memiliki nilai rata-rata yang lebih tinggi dari hasil belajar siswa kelas kontrol.

Tabel 4. Hasil Pengujian Reliabilitas Instrumen Soal

\begin{tabular}{lc}
\hline \multicolumn{1}{c}{ Keterangan } & Nilai \\
\hline Jumlah Varian Item & 19,42 \\
Varian Total & 8,92 \\
Reliabilitas $\left(\mathrm{r}_{11}\right)$ & 0,87 \\
Kategori & Sangat Tinggi \\
\hline
\end{tabular}


Dari Tabel 4 di atas didapat hasilnya yaitu Jumlah Varian Item sebesar 19,42, Varian Total sebesar 8,92, $\mathrm{r}_{11}$ (reliabilitas instrument) sebesar 0,87 dan dinyatakan dalam Kategori Sangat Tinggi.

\section{Hasil Belajar Biologi Kelas Eksperimen $\left(\mathrm{X}_{1}\right)$}

Data yang diperoleh berdasarkan hasil penelitian metode eksperimen dengan menggunakan Model pembelajaran kooperatif tipe Think Pair Square(TPSq) yang dikombinasikan dengan pendekatan Problem Solving pada siswa yang menjadi sampel penelitian (n) sebanyak 30 orang siswa, total nilai hasil belajar yang diperoleh $\left(\sum X\right)$ sebesar 2390, nilai terbesar siswa (Xmax) adalah 100 dan nilai terkecil (Xmin) adalah 60, dengan rata-rata nilai $(\overline{\mathrm{X}})$ sebesar 80 , median/nilai tengah $(\mathrm{Me})$ sebesar 80 dan nilai yang paling sering keluar/modus (Mo) sebesar 80. Data hasil penelitian kelas eksperimen $\left(\mathrm{X}_{1}\right)$ ditampilkan dalam distribusi frekuensi pada gambar grafik berikut:

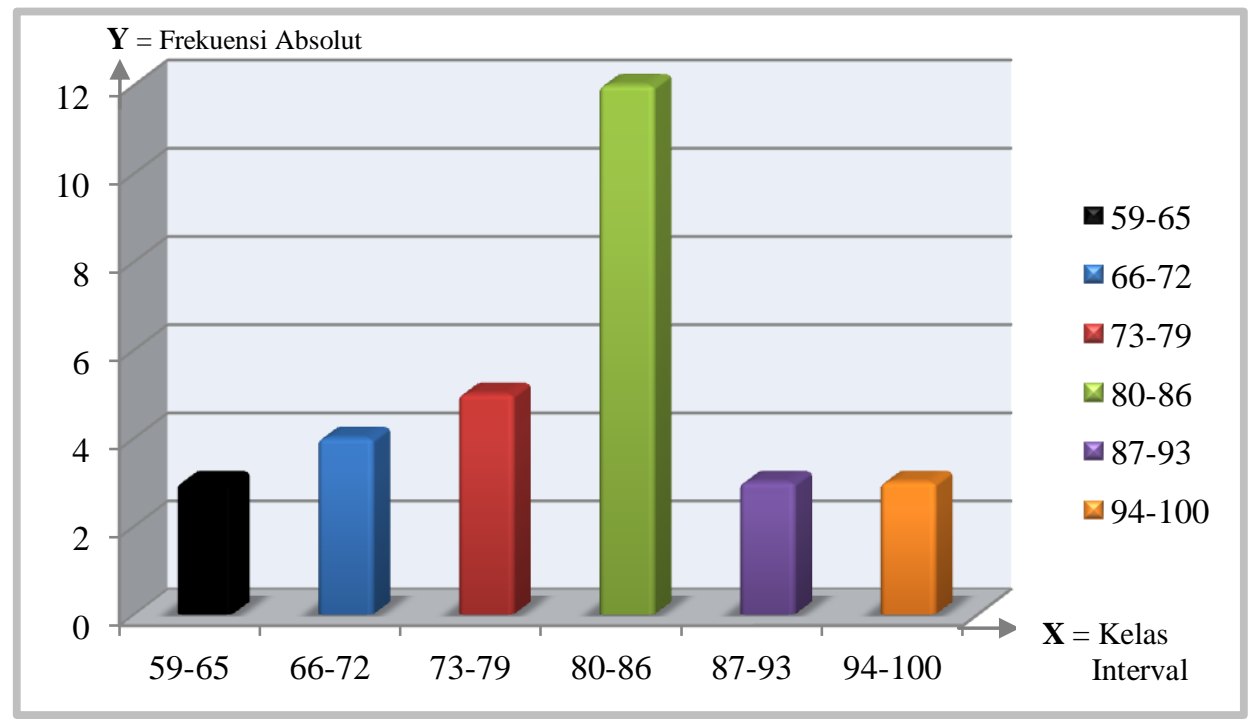

Gambar 1. Grafik Distribusi Frekuensi Data Hasil Penelitian Kelas Eksperimen.

Berdasarkan hasil penelitian yang telah ditabulasi dalam distribusi frekuensi dan divisualisasikan diatas, terlihat bahwa dari 30 orang siswa sampel penelitian kelas eksperimen $\left(\mathrm{X}_{1}\right)$ didapat rata-rata $(\overline{\mathrm{X}})=80$, Standar deviasi $(\mathrm{S})=9,55$ dan $\operatorname{Varian}\left(\mathrm{S}^{2}\right)=$ 91,26, terdapat 18 orang siswa atau $60 \%$ diatas rata-rata, serta 12 orang siswa atau $40 \%$ dibawah rata-rata. Dalam hal ini, tingginya pencapaian prestasi belajar siswa dimungkinkan karena dengan proses pembelajaran pada kelas eksperimen $\left(\mathrm{X}_{1}\right)$ 
memberikan kesempatan pada siswa untuk terlibat secara aktif dalam menemukan suatu pengetahuan dan menambah keseriusan dalam belajar. Sedangkan ditinjau dari pencapaian kriteria ketuntasan belajar ( $\mathrm{KKM}=70,00)$, hasil penelitian menunjukkan bahwa 3 orang siswa atau $10 \%$ tidak tuntas dan 27 orang siswa atau $90 \%$ tuntas setelah mengikuti proses pembelajaran pada kelas eksperimen $\left(\mathrm{X}_{1}\right)$ dengan rata-rata nilai $(\overline{\mathrm{X}})$ 80. Nilai terendah yang diperoleh siswa adalah 60 adalah 3 orang siswa atau 10\% dan terdapat 1 siswa atau $3 \%$ memperoleh nilai sempurna 100 .

\section{Hasil Belajar Biologi Kelas Kontrol dengan Metode Ceramah $\left(\mathbf{X}_{2}\right)$}

Data yang diperoleh berdasarkan hasil penelitian kelas kontrol dengan menggunakan metode ceramah pada siswa yang menjadi sampel penelitian (n) sebanyak 30 orang siswa, total nilai hasil belajar yang diperoleh $\left(\sum X\right)$ sebesar 2045, nilai terbesar siswa (Xmax) adalah 90 dan nilai terkecil (Xmin) adalah 45, dengan rata-rata nilai $(\bar{X})$ sebesar 68, median/nilai tengah (Me) sebesar 70 dan nilai yang paling sering keluar/modus (Mo) sebesar 70. Data hasil penelitian kelas kontrol dengan menggunakan metode ceramah $\left(\mathrm{X}_{2}\right)$ ditampilkan dalam distribusi frekuensi pada grafik berikut:

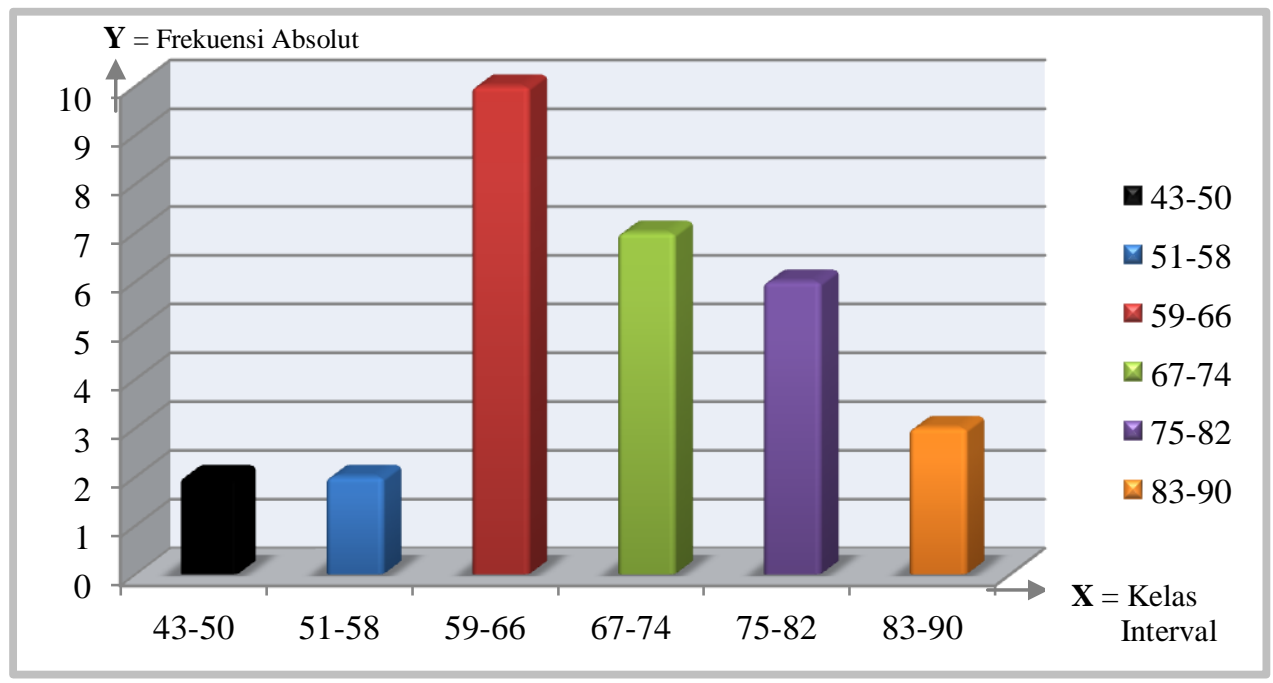

Gambar 2. Grafik Distribusi Frekuensi Data Hasil Penelitian Kelas Kontrol.

Berdasarkan hasil penelitian yang telah ditabulasi dalam distribusi frekuensi dan divisualisasikan diatas, terlihat bahwa dari 30 orang siswa sampel penelitian kelas kontrol $\left(\mathrm{X}_{2}\right)$ didapat rata-rata $(\overline{\mathrm{X}})=68$, Standar deviasi $(\mathrm{S})=10,30$ dan Varian $\left(\mathrm{S}^{2}\right)=106,01$. terdapat 15 orang siswa atau 50\% diatas rata-rata, serta 15 orang siswa atau 50\% dibawah rata-rata. 
Ditinjau dari pencapaian kriteria ketuntasan belajar $(\mathrm{KKM}=70,00)$, hasil penelitian menunjukkan bahwa 15 orang siswa atau 50\% tidak tuntas dan 15 orang siswa atau $50 \%$ tuntas setelah mengikuti proses pembelajaran pada kelas kontrol $\left(\mathrm{X}_{2}\right)$ dengan rata-rata nilai $(\overline{\mathrm{X}})$ 68. Nilai terendah yang diperoleh siswa adalah 45 , yang diperoleh 1 orang siswa atau 3\% dan tidak terdapat siswa yang memperoleh nilai sempurna $=100$.

Berdasarkan uji normalitas kelas eksperimen dan kelas kontrol diperoleh harga $\mathrm{L}_{0}$ dan $\mathrm{L}_{\mathrm{t}}$ pada taraf nyata 0,05 untuk $\mathrm{n}<30$ seperti pada Tabel berikut:

Tabel 5. Hasil Uji Normalitas Kelas Eksperimen dan Kelas Kontrol.

\begin{tabular}{cccccc}
\hline Kelas & $\mathbf{N}$ & $\alpha$ & $\mathbf{L}_{\mathbf{0}}$ & $\mathbf{L}_{\mathbf{t}}$ & Keterangan \\
\hline Eksperimen & 30 & 0,05 & 0,1333 & 0,161 & Normal \\
Kontrol & 30 & 0,05 & 0,1247 & 0,161 & Normal \\
\hline
\end{tabular}

Berdasarkan tabel tersebut terlihat bahwa kedua kelas eksperimen dan kelas kontrol memiliki $\mathrm{L}_{0}<\mathrm{L}_{t}$, berarti kedua kelas sampel terdistribusi normal. Selanjutnya berdasarkan hasil perhitungan uji normalitas menggunakan uji Liliefors, untuk kelas Eksperimen $\left(\mathrm{X}_{1}\right)$ dengan menggunakan Model pembelajaran kooperatif tipe Think Pair Square (TPSq) yang dikombinasikan dengan pendekatan Problem Solving diperoleh nilai $\mathrm{L}_{\mathrm{hitung}}$ sebesar 0.1333 dan untuk kelas Kontrol $\left(\mathrm{X}_{2}\right)$ dengan menggunakan metode Ceramah diperoleh nilai $\mathrm{L}_{\text {hitung }}$ sebesar 0.1247 , karena nilai $\mathrm{L}_{\text {hitung }}$ untuk setiap kelas lebih kecil dari nilai kritis $\mathrm{L}_{\text {tabel }}=0,161, \alpha=0,05$ maka hipotesis nol $\left(\mathrm{H}_{0}\right)$ diterima, berarti data dari kedua kelas berdistribusi normal dan uji dapat dilanjutkan untuk melihat homogenitas asal populasi kelompok data.

Tabel 6. Hasil Uji Homogenitas Kelas Eksperimen dan Kelas Kontrol.

\begin{tabular}{ccccc}
\hline Kelas & $\mathbf{A}$ & $\mathbf{F}_{\text {hitung }}$ & $\mathbf{F}_{\text {tabel }}$ & Kesimpulan \\
\hline $\begin{array}{c}\text { Eksperimen } \\
\text { Kontrol }\end{array}$ & 0,05 & 0,86 & 1,86 & Homogen \\
\hline
\end{tabular}

Hasil perhitungan uji homogenitas diperoleh nilai $F_{\text {hitung }}$ sebesar 0,86 Sedangkan nilai $\mathrm{F}_{\text {tabel }}$ pada signifikansi $\alpha 0,05$ sebesar 1,86 , karena nilai $\mathrm{F}_{\text {hitung }}$ lebih kecil dari $\mathrm{F}_{\text {tabel }}$ maka pengujian menerima hipotesis nol $\left(\mathrm{H}_{0}\right)$, sehingga dapat disimpulkan bahwa data dari kedua kelas bersifat homogen atau berasal dari variansi populasi yang sama.Dengan telah terujinya normalitas data dan homogenitas variansi populasi kelompok data maka dari kedua kelas penelitian telah memenuhi persyaratan analisis untuk menguji hipotesis. 
Pengujian hipotesis digunakan uji-t. Nilai hasil uji perbedaan dua rata-rata dapat dilihat pada tabel berikut:

Tabel 7. Hasil Uji Perbedaan Dua Rerata Tes Akhir.

\begin{tabular}{cccc}
\hline Kelas & $\mathbf{t}_{\text {hitung }}$ & $\mathbf{t}_{\text {tabel }}$ & Kesimpulan \\
\hline $\begin{array}{c}\text { Eksperimen } \\
\text { Kontrol }\end{array}$ & 4,69 & $\alpha=0.05=2,042$ & Hipotesis diterima \\
\hline
\end{tabular}

Berdasarkan hasil perhitungan uji beda menggunakan uji t satu pihak, diperoleh nilai $t_{\text {hitung }}$ dari perbandingan rata-rata antara kelompok perlakuan sebesar 4,69 sedangkan nilai $t_{\text {tabel }}$ uji $\mathrm{t}$ satu pihak pada taraf signifikan $(\alpha=0,05)$ dengan jumlah sampel untuk setiap kelompok perlakuan (n) sebanyak 30 siswa adalah sebesar 2,042. Nilai $t_{\text {hitung lebih }}$ besar dari nilai $t_{\text {tabel }}$ maka pengujian menerima hipotesis alternatif $\left(\mathrm{H}_{\mathrm{a}}\right)$, yaitu terdapat perubahan hasil belajar yang signifikan dari Model pembelajaran kooperatif tipe Think Pair Square (TPSq) yang dikombinasikan dengan pendekatan Problem Solvingdalam pembelajaran Biologi pada siswa kelas VIII di SMP Negeri 5 Batam.

Rata-rata nilai $\left(\mu \mathrm{X}_{1}\right)$ sebesar 80 lebih baik dibandingkan dengan siswa yang mengikuti pembelajaran menggunakan metode Ceramah dengan rata-rata nilai $\left(\mu \mathrm{X}_{2}\right)$ sebesar 68 dan menolak hipotesis nol $\left(\mathrm{H}_{0}\right)$, yaitu Tidak terdapat perubahan hasil belajar yang signifikan dari penerapan Model pembelajaran kooperatif tipe Think Pair Square(TPS $q$ ) yang dikombinasikan dengan pendekatan Problem Solving dalam pembelajaran Biologi pada siswa kelas VIII di SMP Negeri 5 Batam.

Dari hasil perhitungan dengan uji-t didapat harga $t_{\text {hitung }} 4,69$ dan pada taraf nyata 0,05 didapat harga $t_{\text {tabel }} 2,042$. Karena $t_{\text {hitung }}>t_{\text {tabel }}$ berarti bahwa $t_{\text {hitung }}$ berada di luar daerah penerimaan $\mathrm{H}_{0}$, oleh karena itu dapat dikatakan bahwa hipotesis kerja diterima. Dapat disimpulkan bahwa terdapat pengaruh yang berarti hasil belajar siswa antara kelas eksperimen yang diberikan perlakuan dengan menggunakan model kooperatif tipe TPS $q$ yang dikombinasikan dengan pendekatan Problem Solving dibandingkan dengan kelas kontrol yang hanya menggunakan metode ceramah.

Berdasarkan dari hasil analisis data tes akhir didapat rata-rata hasil belajar Biologi siswa pada kelas eksperimen 80,00 dan pada kelas kontrol 68,00, berarti hasil belajar biologi siswa dengan model pembelajaran TPSq yang dikombinasikan dengan Problem Solving lebih tinggi dari pada dengan menggunakan metode ceramah. Hasil belajar pada 
kelas eksperimen lebih tinggi daripada kelas kontrol disebabkan adanya penerapan model pembelajaran $T P S q$ yang dikombinasikan dengan pendekatan Problem Solvingkepada siswa di kelas eksperimen.Model pembelajaran $T P S q$ ini menjadikan siswa termotivasi untuk belajar biologi. Adanya motivasi menumbuhkan keinginan siswa untuk lebih giat dan rajin dalam belajar sehingga mendapatkan hasil belajar yang memuaskan, karena motivasi adalah modal dasar dalam proses belajar.

Fathurrohman dan Sutikno (2007) menyatakan bahwa "Dalam kegiatan belajar, motivasi tentu sangat diperlukan, sebab seseorang yang tidak mempunyai motivasi dalam belajar, tidak akan mungkin melakukan aktivitas belajar". Selain itu dengan adanya tugas dalam bentuk Problem Solving dalam pembelajaran dapat menumbuhkan keinginan siswa untuk belajar lebih tekun. Sebagaimana yang dikemukakan Sriyono (2005) bahwa pemberian tugas bertujuan agar siswa lebih tekun, rajin, dan giat belajar.Dalam pelaksanaan pembelajaran dengan menggunakan model pembelajaran TPS $q$ yang dikombinasikan dengan pendekatan Problem Solvingini diberikan tugas berupa PKPS, siswa termotivasi semangat dalam mengerjakan tugasnya karena siswa berusaha menyelesaikan sendiri tugasnya agar dapat membantu dan menjelaskan kepada temannya mengenai tugas yang dikerjakan.

Sedangkan hasil uji hipotesis dengan uji t pada taraf nyata 0,05 dan derajat kebebasan 55 diperoleh harga $t_{\text {hitung }} 4,69$ dan harga $t_{\text {tabel }} 2,042$. Dengan demikian $t_{\text {hitung }}>$ $t_{\text {tabel }}$ yang berarti bahwa $\mathrm{H}_{1}$ diterima. Dengan demikian dapat dinyatakan bahwa terdapat pengaruh yang berarti penerapan model pembelajaran kooperatif tipe $T P S q$ yang dikombinasikan dengan pendekatan Problem Solving terhadap hasil belajar biologi siswa kelas VIII SMP Negeri 5 Batam. Berdasarkan uraian di atas maka penerapan model pembelajaran TPSq yang dikombinasikan dengan pendekatan Problem Solving memberikan pengaruh yang berarti terhadap hasil belajar siswa. Ini terbukti dengan di perolehnya nilai akhir penelitian yang lebih tinggi pada kelas eksperimen dan berarti secara statistik.

\section{KESIMPULAN}

Berdasarkan dari hasil analisis data tes akhir didapat rata-rata hasil belajar Biologi siswa pada kelas eksperimen 80,00 dan pada kelas kontrol 68,00. Berarti hasil belajar biologi siswa dengan model pembelajaran TPSq yang dikombinasikan dengan Problem 
Solving lebih tinggi dari pada dengan menggunakan metode ceramah. Disebabkan adanya penerapan model pembelajaran TPSq yang dikombinasikan dengan pendekatan Problem Solvingkepada siswa di kelas eksperimen. Model pembelajaran TPSq ini menjadikan siswa termotivasi untuk belajar biologi.Berdasarkan hasil penelitian yang telah dilakukan maka dapat disimpulkan bahwa penggunaan model pembelajaran kooperatif tipe $T P S q$ yang dikombinasikan dengan pendekatan problemsolving berpengaruh positif yang berarti terhadap peningkatan hasil belajar biologi siswa kelas VIII SMP Negeri 5 Batam tahun pelajaran 2013/2014.

\section{REFERENSI}

Arikunto, Suharsimi. 2012. Dasar-dasar Evaluasi Pendidikan. Bumi Aksara. Jakarta.

Djamarah, Syaiful Bahri dan Zain, Aswan. 2006. Strategi Belajar Mengajar. PT Rineka Cipta. Jakarta.

Fathurrohman, P., dan Sutikno, S. 2007. Strategi Belajar Mengajar Melalui Penanaman Konsep Umum \& Konsep Islami. PT Refika Aditama. Bandung.

Hamalik, Oemar. 2004. Kurikulum Dalam Pembelajaran. Bumi Aksara. Jakarta.

Lie, Anita. 2004. Cooperatif Learning, Mempraktikkan Cooperatif Learning di Ruangruang kelas. Jakarta: Grasindo.

Linsari. 2006. Upaya Peningkatan Hasil Belajar Siswa dengan Menggunakan Landform Sederhana (Maket) di SMP Negeri 5 Pariaman Kota Pariaman. Jurnal Pendidikan.1 (1): 22-26.

Lufri. 2007. Strategi Pembelajaran Biologi. UNP PRESS. Padang.

Martasari, Rika Yeni. 2008. Pengaruh Model Pembelajaran Kooperatif Tipe Think Pair Square Terhadap Aktivitas dan Hasil Belajar Biologi Siswa Kelas X Semester I Tahun Pelajaran 2007/2008 SMA 1 Kec. Situjuh Limo Nagari Kab.50 Kota. Skripsi UNP. (tidak diterbitkan).

Melinda, Yopa. 2009. Pengaruh Penerapan Model Pembelajaran Tipe Think Pair Square Yang Dilanjuti Dengan Kuis Terhadap Hasil Belajar Biologi Siswa SMP Negeri 22 Padang Tahun Ajaran 2008/2009. Skripsi UNP. (tidak diterbitkan).

Sardiman. 2006. Interaksi dan Motivasi Belajar Mengajar. Raja Grafindo Persada. Jakarta. Sudjana. 2005. Metoda Statistika. Tarsito. Bandung. 
Masrudi, Destaria Sudirman, Ramses : Pengaruh model pembelajaran kooperatif...

Slameto. 2003. Belajar dan Faktor-faktor Yang Mempengaruhinya. Rineka Cipta. Jakarta.

Sriyono, dkk. 2005. Berbagai Pendekatan Dalam Proses Belajar Mengajar. PT Remaja Rosda Karya. Bandung.

Yusuf, A. Muri. 2007. Metodologi Penelitian. UNP Press. Padang. 